\title{
Impact of Integration Process for Development of Economic Agents
}

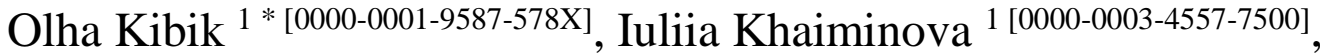 \\ Kateryna Belous 2 [0000-0001-7080-7932]

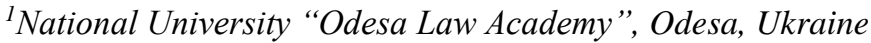 \\ ${ }^{2}$ Odesa National Maritime University, Odesa, Ukraine \\ "kibik@ukr.net
}

\begin{abstract}
Global economy, national economic systems, regions and industries, business-structures have advantages, taking part in integration processes. The aim of the article is to study the influence of integration processes of different levels on the results of economic agent's development. The dialectical method allowed to investigate the definition of the integration and the integration process. The method of system analysis was used to study the development of integration associations. The system-structural method helped to study basic measures to the development of the integration process in the state economic system and its components. The positive and sometimes the negative integration effects are systematized. Integration processes are investigated in different levels. Development trends of integration activities in the field of maritime transport are identified in the article. The trends in the development of integration activities in the maritime transport as a structure-forming sphere of the national economy of Ukraine are identified in the article.
\end{abstract}

Keywords: integration, iintegration process, integration structures, economic agent, development.

\section{INTRODUCTION}

Present environment requires that every economic agent must maintain an optimal level of security and ensure there development. Research of processes of globalization and integration on different levels based on the impact for economic agent's economic security becomes more actualizing. Integration processes are proceeding on each level of economic activity. Integration is often considered as a factor and potential for development of enterprises, regional's and national economy growth. On the other hand, in certain cases, integration can generate additional challenges to the potential of economic agent's development. There are various factors that determine the direction, level and strength of integration influence on the indicators of economic agents' activities and development. In our view, considerable attention should be paid to the problems identified by agents, which are the structural elements of the state's economic system, and to the state itself as an economic agent. Functioning of transport infrastructure which provided by enterprises of different modes of transport, in particular maritime, has been considered as an example of the state economic system's structure - forming elements.
The studies of the definition «integration», types and specificity of integration process has paid considerable attention in science articles. Balassa Bela analyzed integration processes and formed the Theory of Economic Integration [1, pp. 73-130]. Molle Willem, Pelkmans J. systematized theoretical positions and practical experience of European Integration [2, pp. 24$48,3]$.

The integration vector of Ukraine determines the interest of many scientists to explore the issues of European integration, to identify risks and opportunities, mechanisms for managing and implementing the integration process [4-12]. Integration processes are investigated in different industries (agriculture, tourism and transport). Formation and development of integration structures were investigated by Borsi Mihaly T., Norbert Metiu, M.V. Bosovskaya and others [13, 14]. It's worth paying attention to M.V. Bosovskaya's works which comprehensive studies of approaches to the definition of integration were carried out, systematized the theoretical concepts of integration processes and determined the economic essence of integration processes [13]. V.V. Markovych's work was devoted to examining the cross-border cooperation in Ukraine in terms of European integration[15]. The newest levels of 
international integration processes on global, georegional, national- and firm- levels have been analyzed by Filipenko A.S. [16]. The issue of involving the Black Sea economic region in integration processes have been devoted works of many Ukrainian scientists. They defined potential of interregional cooperation of the Black Sea economic region, specialties of the black sea economic region development in terms of European integration etc. [17-21].

\section{RESEARCH METHODOLOGY}

Despite the considerable number of scientific publications on the development of integration processes in the world and in Ukraine, the issues of assessment of the impact of integration processes on the results of development of economic agents of different levels require research continues.

The aim of the article is to study the influence of integration processes of different levels on the results of economic agent's development.

The study is based on the use of general scientific and special-scientific methods of scientific knowledge. The dialectical method allowed to investigate the definition of the integration and the integration process. The method of system analysis [22] was used to study the development of integration associations. The systemstructural method helped to study basic measures for development in the integration [23] process of the state economic system and its components.

\section{RESULTS OF THE RESEARCH}

Integration is a process which is going on different levels and different directions. There are two main levels of integration process - macro and micro- level.

There are many definitions of "integration" and "integration process" in scholars' studies. The integration process might be considered on micro - level (business relationships between individual companies and within large business entities) and macro-level (regional integration agreement levels) [6]. In researching approaches to defining economic integration, it should be noted that economic integration is viewed as: process of developing deep and sustainable relationships and labour division between economic units and nations, creation of economic complexes within cluster, region or country; integration of states or individuals (or group of people international structures) in field of energy, trade, transport, industry and business, which implies common economic space which includes the reduction or elimination of trade barriers, free trading and capital exchange [1, pp. 73-130]; the process of interpenetration, convergence of neighbouring country's economy into a single economic complex with stable economic relations at the micro-level (corporate) and macro-level (level of arrangement among countries), the result of which is the development and implementation of a general strategy for economic and political development of countries [6]; the process of convergence and integration of economics and economic activities of individual countries [24].

V.M. Bosovskaya defines six levels of the integration process: nanolevel (process, function, unit, employee), microlevel (enterprises), mesolevel (region), macrolevel (national economy), megalevel (nations integration), meta level (global economy) [13].

A.S. Filipenko emphasizes the importance of research on integration processes at the global, national and corporate levels [16].

Researchers define two forms of the integration processes: inter-civilization (agreements between civilizations (globalization) and interstate (unification of states (international integration). Global integration is defined as a means of unification nations that promotes effective interaction between them at all institutional levels of society development and is based on realization of their common interests $[1,14,21]$.

Modern forms of global integration are individual and collective. Regional aspects of integration are studied at the micro and macro levels.

The studies of industrial integration at the micro level are intensifying at the same time. In this case, integration is seen as effectively operating on the basis of the organizational, economic and territorial community of integration of specialized agricultural, processing, transport and other industries and production. Microlevel integration involves the process of creating a vertically integrated utility.

The integration of the capital of companies with different goals is a very important process, but not researched enough, especially in the transport industry.

Taking into account results of different scholars research, integration process we consider as the process in which individual economic agents at the micro-, macro, and (or) international levels transfer part of their rights in favour of unified institutional structure which have been created for the realization of common interests. The integration is a process of unification different systems for common activities in order to achieve this goal. There are certain consequences from integration processes.

The effects of integration processes can be classified into different characteristics. The main important types of integration effects are economic, social and ecological. The integration effects are conditioned by the integration process level. In practice, especially in the context of activation of the development of applying blue economy concepts, all these types of effects are closely interrelated. Economic integration leads to two types of effects [25]. Static effects are apparent immediately after the integrated structure is created. Reduction of administrative costs at border and customs departments, 
create trade relations, development or decline such relations are the static effects of integration. Dynamic effects appear as a result from integration functioning.

Increasing investments, access to technologies or (and) recourses of integration formation, foundation of common market and market expansion, common resolution of complex problems, increased competitive advantages and competitive positions, accelerated scientific and technological progress and economic growth are the examples of dynamic effects. As we can see from the UN statistics and reports, many countries are participating in the integration process, developing tendencies of inter-trade economic relations, new bilateral and multilateral free trade agreements [26].

The main results of regional economic integration are synchronization of economic and social development of counties, convergence of development rates, deepening the interdependence of economies and integration of countries, accelerating GDP and labour productivity growth, increasing production, reducing costs and shaping regional trade markets. Macroeconomic indicators of the main economic groupings demonstrated in Table 1 and Figure 1.

Table 1. The main indicators of the development of integration associations in 1993 and 2018, compiled by the authors from information data [27-29]

\begin{tabular}{|c|c|c|c|c|c|c|c|c|c|c|}
\hline \multirow{2}{*}{$\begin{array}{l}\text { Integration } \\
\text { associations }\end{array}$} & \multicolumn{5}{|c|}{1993} & \multicolumn{5}{|c|}{2020} \\
\hline & 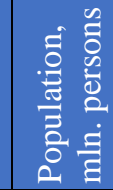 & $8 \frac{0}{0}$ & है & 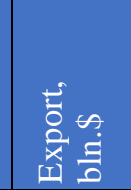 & 总 & 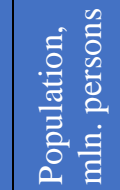 & 8 & $\frac{\hat{\tilde{E}}}{\hat{\tilde{E}}}$ & 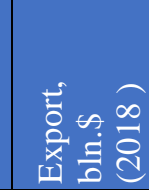 & 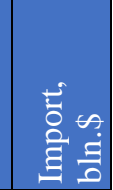 \\
\hline NAFTA & 386,3 & 7,99 & 20699 & 873,55 & 960,31 & 489 & 24,36 & 49811 & 2564,5 & 3559,8 \\
\hline $\mathrm{EU}$ & 479,0 & 7,53 & 15732 & 1953,77 & 1976,27 & 513,4 & 18,58 & 36199 & 6465,4 & 6494,2 \\
\hline ASEAN & 468,8 & 0,52 & 1115 & 261,1 & 265,61 & 649,6 & 2.9 & 4537 & 1447,3 & 1435,6 \\
\hline $\begin{array}{l}\text { MERCOS } \\
\text { UR }\end{array}$ & 227,2 & 0,72 & 3193 & 83,1 & 80,51 & 304,7 & 2,6 & 8622 & 351,5 & 287,3 \\
\hline
\end{tabular}

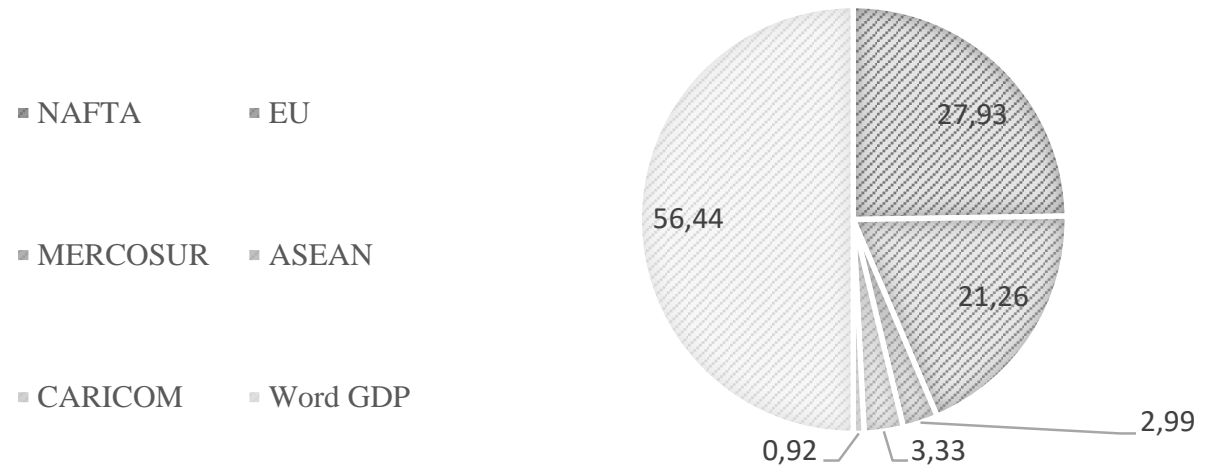

Figure 1 The share of leading economic groups in the value of world GDP in \%, compiled by the authors from information sources [27-29]

The positive effects of regional integration are the increase of economic growth and convergence of economic development indicators of the countries belonging to the integration group. Stabilization of prices and the tendency of decreasing unemployment in countries, which join the economic integration grouping, has shown this. Attracting external sources of funding from more developed allied countries allows less developed allies to accelerate economic development as they approach the economically stronger partner countries. The manifestation of this effect depends on the degree of integration. In economic groupings with less integration involvement, these effects appear in a more extended period [30].

The cross-border integration is based on increasing integration processes at the mesolevel. Forming of economic connections and trade agreements between border regions of two countries in format of cross- border cooperation, cross-border partnerships there are forms of 
cross-border integration processes. The cross-border sectoral integration is a process of economic integration of a particular sector and economic areas, which are taking place in cross-border areas of different counties. The purpose of involving a country's region into the integration process is to increase the efficiency of using their potential to ensure competitiveness as a part of the regional development mechanism.

In the study "The European map of Ukraine. Rating of European Integration of Regions" prepared by NEC analysts in cooperation with the Government Office for Coordination on European and Euro-Atlantic Integration, examines the degree of involving Ukrainian regions to European economic integration by 34 indicators of eight spheres: economic integration, infrastructure, local democracy and accountability, educational, scientific and cultural integration, energy and environmental policy, gender equality and communication [31]. According to the results of the study, there are three leaders in the degree of EU's integration - Lviv, Ivano-Frankivsk, and Vinnytsia regions. However, levels of these indicators are lower in comparison with regions of developed countries. The fact that Odessa region occupies only a fifth position in the rating is of concern. In maritime countries, coastal regions are leaders in the integration processes. Odessa region is the leader in the development infrastructure indicator (22.7 points out of 27). The Odessa region was in one of the last places, gaining 11.39 points out of 50 for the indicator of economic integration. According to the indicators "educational, academic, and cultural integration" the region occupies 3 rd place, "Energy and environmental policy" - 2 nd place, "Gender equality" - 17th place, "Communication of European integration" - 24th place (which is one of last), "Broader partnership" - 3rd place. Odessa region has twenty-four valid inter-regional international agreements with EU member countries, 26 twin cities from EU Member countries and consulates of EU Member States. According to the indicator "Local democracy and Accountability" Odessa region took only 20th place. Mykolaiv region was among the leaders for indicating "Growth of goods exports to EU market» (grain and oil, food goods exports). There are presuppositions for considering integration as an organizational form of operation of an entity (for example, an integrated structure). Outsourcing, cluster, concern, cartel, pool, corporation, strategic alliance can be considered as organizational forms of the integration processes.

The mergers and acquisitions are the most common micro-level integration processes. According to the economic report, in the first half of 2019, the total value of M\&A in the world reached \$ $1.86 \mathrm{bln}$. This is on $21 \%$ higher than in the second half of 2018 ( $\$ 1.5 \mathrm{bln}$ ), albeit $8 \%$ less than in the first half of 2018 (\$ 2 bln on announced deals). M\&A deals declined $12 \%$ in the second half of 2019 to one of their lowest levels since the first half of 2019, starting in 2015 [32].

\section{DISCUSSION OF RESULTS}

Integrated structures can generate competitive advantages in different areas [6]. In the financial sphere, advantages have reduced costs, growth of profit and profitability level, generated additional financial resources (such as attracting investments), and increased the capital cost, implementation of investment projects.

In the management sphere, integrated structures can get the opportunity for attraction to strategic cooperation with partners and foundation long-term relationships and to ensure the cooperation between memberships. In the management sphere advantages are the concentration of activity, potential of specialization and division of labour, excluding double functions, consulting, management, science support, rationalization of organizational and management structures, communications and business processes etc.

In conditions of all types of resources constrained, the concentration of the resource potential is ensured, which allows increased efficiency of its use by optimizing the composition and structure of resources.

As a result, opportunities to attract additional resources to ensure development are being created. Formation of a common market, formation of a positive image, strengthening of a competitive position are possible advantages in the marketing sphere. It should be noted such important positive aspects of the integration process as a formation for common information system for members, which is important in the condition of development digitalization of the business-process. The effects in science and the technological sphere are a realization of joint scientific, educational, research projects, growth of innovative potential.

In the conditions of development of the corporate responsibility of economic agents, the consequences of integration activities in the environment (compliance with environmental requirements and minimization of negative impact on the environment) and social spheres (compliance with requirements of social standards, improvement of working conditions, development of a motivational component, corporate programs and projects) are important. Integration processes are the most important factors in the development of the global transport market and its segments.

Taking into account the role of the maritime industry in the global transport system foundation it is important to consider the positive and negative effects of integration activities in maritime transport. Integration processes of maritime industries are an important component of the national transport complex integration into global economic space and European Economic Area. The pressing issue is to identify and ensure the 
leading role of maritime transport in the development of regional integrated structures of coastal regions. Processes of clustering, corporatization and foundation strategic alliances have been developing in the maritime industry at micro-level.

The cluster approach to ensure creation and developing maritime activity systems should be based on the view that cluster structures are recognized as one of the most effective forms of integrated structures of innovative type, forms of regional innovation development. Clusters influence on market competition. Thus, compete in not only individual transport enterprises, but transport complexes, which allows optimization costs through joint technological cooperation. Cluster structures with maritime transport involved are forming special economic space in order to expand free trade, free movements of labour and capital and serve as the structural elements of the global system.

Competitive and investment attract economic models which ensure a high standard and quality of human life is being formed on a cluster basis. Modern condition of business development requires resources and competencies that are often not possessed by individual companies. Clusters combine competition and cooperation, "common effects", "flexible specialization", use effects of economies of scale and growth poles.

Integration in the field of maritime business develop successfully on the basis of public - private partnership and expanding the scope of self-regulatory principles.

The optimal correlation of self-regulation and public regulation of integration activities at different levels of activity of national transport enterprises has been determined by taking into account as follows:

- determining the place and role of self-regulation in the organizational and legal provision of creation and development of integration;

- taking into account the need and limits of state intervention in the sphere of organizational and legal support for the creation and development of integration entities, which takes into account possible economic and legal incentives for industrial and innovation cooperation as a condition for increasing the competitiveness of individual structures and the economy as a whole;

- public regulation and self-regulation of economic activity with organizational and legal support for creation and development of integration activities has been balanced and combined.

\section{CONCLUSIONS}

Integration processes should be considered on all levels of the economic system.

Global economy, national economic systems, regions and industries, business-structures have advantages, taking part in integration processes. However, the positive and sometimes the negative effects aren't limited to the economy. Policy and programs of the integration development allows solving ecological, political issues, social development within society. Integration influence on security of economic and political systems. Research into the integration processes have been updated. In researching into interaction between members of integration unity, particular attention should be paid to study of structure-forming spheres of activity.

There are transport industry enterprises, including maritime business which are actively involved in the formation and (or) functioning integration groupings of regional - national and international levels. Influences of integration processes on economic security of economic agents of different levels should be studied, taking into account the effects of internal and external factors.

\section{REFERENCES}

[1] Balassa, Béla (1973), The Theory of Economic Integration, London: George Allen \& Unwin, UK.

[2] Molle, Willem (2006), The Economicss of European Integration. Theory. Practice. Policy, 5th ed, London: Routladge, Taylor and Frances Group, UK.

[3] Pelkmans, J. (1997), European Integration. Methods and Economic Analysis, Longman, Harlow, New York, USA.

[4] Todoschuk, A.V. Batiuk, I.I. and Sheremeta, A.I. (2017), "Ukraine in integration processes: risks and advantages", available at: http://molodyvcheny.in.ua/files/journal/2017/5/16 8.pdf.

[5] Payanova, L.V. (2019), "Improvement of the mechanisms of state governance by development of economic cooperation between Ukraine and the EU'. Abstract of Ph.D, dissertation, Ukrainian State Employment Service Training Institute, Kyiv, Ukraine.

[6] Polgorodnik, O.V. (2017), "Integration of Ukraine into the European Economic Space: theoretical and methodological provisions", Herald of the DSEA, [Online], vol. 1 (40), pp. 145-151, available at: http://www.dgma.donetsk.ua/science_public/ddma /Herald_1(40)_2017/article/28.pdf.

[7] Semenyuk, E.P. Kotlyarevsky, Ya.V. Kniaziev, S.I. and Melnikov, O.V. (2017), "Information Economy: the Formation of Special-Purpose Categorical Framework", Sci. Innov. vol. 13, no. 3, pp. 5-19, DOI: $10.15407 /$ scine 13.03 .005

[8] Kotlyarevsky, Ya.V. Melnychenko, A.A. Ivanytska, O.M. Semenyuk, E.P. Kniaziev, S.I. and 
Melnikov, O.V. (2020), "New Economy: Evolution of Forms and Research Methodology", Sci. Innov., vol. 16 , no. 1 , pp. 15-30, DOI: $10.15407 /$ scine 16.01 .015

[9] Sokolovska, A.M. and Kotlyarevsky, Ya.V. (2020), "Scientific Discourse of Populism: Aspects of Economy and Tax Policy", Sci. Innov., vol. 16, no. 5, pp. 36-51, DOI: 10.15407/scine16.05.036.0.15407/scine14.05.005

[10] Korystin, O.Ye. (2020), Chapter 4. State Legal Police of Scientific Prediction. Public administration in the digital economy, monograph, Tallinn, Scientific Center of Innovative Researches OU, DOI: 10.36690 PADE

[11] Korystin, Oleksandr and Svyrydiuk, Nataliia (2021), "Activities of Illegal Weapons Criminal Component of Hybrid Threats", Proceedings of the International Conference on Economics, Law and Education Research (ELER 2021), vol. 170, 22 March, pp. 86-91, DOI: 10.2991/aebmr.k.210320.016

[12] Tkachenko, Volodymyr Kwilinski, Aleksy Korystin, Oleksandr Svyrydiuk, Natalia and Tkachenko, Iryna (2019), “Assessment of information technologies influence on financial security of economy", Journal of security and sustainability issues, march, vol. 8, no. 3, pp. 375385, DOI: 10.9770/jssi.2019.8.3(7) 2

[13] Bosovska, M.V. (2015), Integration processes in tourism: monograph, Kyiv National University of Trade and Economics, Kyiv, Ukraine.

[14] Borsi, Mihaly T. and Norbert, Metiu (2015), "The evolution of economic convergence in the European Union”, Empirical Economy, vol. 48 (2), pp. 657-681, DOI:10.1007/s00181-014-0801-2

[15] Markovych, V.V. (2018), "Socio-economic efficiency of cross-border cooperation of Ukraine in terms of European integration", Abstract of Ph.D, dissertation, Vasyl' Stus Donetsk National University, Vinnitsa, Ukraine.

[16] Filipenko, A.S. (2016), "International economic integration: the modern theoretical discourse, Foreign policy and diplomacy: traditions, trends, experience", Institute of international relations Taras Shevchenko National University of Kyiv, vol. 23, pp. 53-60.

[17] Kukharchyk, O.G. (2018), "Perspectives for development of transportation of the black sea region", Ukrainian Journal of Applied Economics, vol. 3, pp. 159-169.
[18] Storogilova, U.L. (2017), "Development of the black sea economic region in the context of public administration and European integration", Black Sea Economic Studies, vol. 17, pp. 125-131.

[19] Regarding the use of the potential of interregional cooperation in the integrated development of the coastal regions of Ukraine, available at: http://old2.niss.gov.ua/articles/968/

[20] Laszlo, Bruszt and Nauro F. (2019), "Campos. Economic integration and state capacity”, Journal of Institutional Economics, vol. 15, pp. 449-468, DOI:10.1017/S1744137418000346

[21] Brou, D. and Ruta, M. (2011), "Economic Integration, Political Integration or Both?", Journal of the European Economic Association, vol. 9(6), pp. 1143-1167, DOI: $10.1111 /$ j.15424774.2011.01037.x

[22] Sara Fatima and Salha Abdullah (2013), "Improving Teaching Methodology in System Analysis and Design using Problem Based Learning for ABET", IJMECS, vol. 5, no. 7, pp. 6068, DOI: 10.5815/ijmecs.2013.07.07

[23] Hanan A. Al-Jubouri (2020), " Integration Colour and Texture Features for Content-based Image Retrieval", International Journal of Modern Education and Computer Science, vol. 12, no. 2, pp. 10-18, DOI: 10.5815/ijmecs.2020.02.02

[24] Rumar, M.V., and Vatamuk-Zelinska, U.Z. (2013), Integration processes in entrepreneurship: monograph, Lviv, Ukraine.

[25] Brada, Josef C. and Mendez, Jose A. (1988), “An Estimate of the Dynamic Effects of Economic Integration", The Review of Economics and Statistics, vol. 70 (1), pp. 163-168, DOI: $10.2307 / 1928166$

[26] Derbenova, Ya.V. (2016), "The development of regional economic integration in the modern conditions", Scientific Bulletin of Uzhhorod National University, vol. 9, pp. 46-49.

[27] World Trade Statistical Review 2019, Appendix tables, WTO, (2019), 179 p.

[28] Kowalikhttps, P. "20 years of NAFTA - trends in trade and the economic effects", available at://www.researchgate.net/publication/283391156 _20_years_of_NAFTA_-

_trends_in_trade_and_the_economic_effects

[29] Statistic of economic integration groups (electronic version), available at https://countryeconomy.com/countries/groups 
[30] Fedirko, N., and Konstantinova, A. (2015), "Macroeconomic effects of international regional economic integration: Global practice and challenges for Ukraine", International economic policy, vol. 1, pp. 155-179.

[31] Levoniuk, T., Fakhurdinova, M., Solodkyy, S. and Shtanieva, A. (2019), The European map of
Ukraine, Rating of European Integration of Regions, New Europe Center, Kyiv, Ukraine.

[32] Global dealmakers: Cross-border M\&A outlook (2019), available at: https://bakertilly.ua/wpcontent/uploads/2019/11/BakerTilly-GlobalDealmakers-Report_FINAL_LRHQ.pdf 